\title{
RUBAYAT HAMZAH FANSURI: KAJIAN STUKTURALISME SEMIOTIKA Rubayat Hamzah Fansuri: A Study Of Semiotic Structuralism
}

\author{
Medri Osno \\ Kantor Bahasa Kepulauan Riau \\ Pos-el: oesnoemedri@gmail.com
}

\begin{abstract}
Abstrak: Penelitian ini bertujuan: pertama, menemukan bentuk struktur Rubayat Hamzah Fansuri; kedua, menemukan makna melalui pembacaan semiotika; ketiga menemukan makna melalui pembacaan heuristik; keempat, menemukan makna melalui pembacaan hermeneutik. Jenis penelitian ini adalah kualitatif dengan pemaparan naratif deskriptif. Pengumpulan data menggunakan metode simak dan teknik catat. Analisis menggunakan kombinasi metode agih dan metode padan yang merujuk pada model analisis strukturalisme-semiotika. Metode agih yang digunakan adalah teknik bagi unsur langsung (BUL). Metode padan yang digunakan adalah teknik pilah unsur penentu (PUP). Analisis makna menggunakan metode padan dengan daya pilah pragmatis yang merujuk pada model analisis semiotika. Sajian hasil analisis data dilakukan dengan metode formal dan informal. Temuan penelitian ini yaitu bentuk struktur bahasa melalui sistem pemakaian diksi memiliki proses sosial yang beragam. Keberagaman ini menentukan dan ditentukan oleh diksi yang terstruktur menurut kebutuhan. Pemaknaan karya secara semiotika ditentukan melalui pembacaan tingkat pertama (heuristik) dan dilanjutkan dengan tingkat selanjutnya, yaitu pembacaan secara hermeneutik. Secara keseluruhan Rubayat banyak menggunakan metafora. Semua itu merupakan "defamiliarisasi" atau "deotomatisasi" untuk menimbulkan daya pesona sajak atau untuk membuat aneh (making strange) sehingga menarik perhatian.
\end{abstract}

Kata Kunci: rubayat, strukturalisme, semiotika

Abstract: This study aims at: first, finding out the form of the structure of Rubayat Hamzah Fansuri; second, finding meaning through semiotic reading; third, finding meaning through heuristic reading; fourth, finding meaning through hermeneutic reading. This type of research is qualitative with descriptive narrative presentation. Data collection technique uses observational method and note taking technique. The analysis applies a combination of distributional method and identity method that refer to the structuralism-semiotic analysis model. The method used is the Ultimate Constituent Analysis (UCA). The identity method used is immediate constituent analysis (ICA). Meaning analysis uses an identity method to pragmatic power that refers to the semiotic analysis model. The presentation of the results of data analysis is carried out by formal and informal methods. The findings of this study are the form of language structure through diction usage systems that have diverse social processes. This diversity determines and is determined by a structured diction according to needs. The meaning of the work in semiotics is determined through the first level reading (heuristics) and continued with the next level, namely hermeneutic reading. Overall Rubayat is full of metafore. All of these are "defamiliarization" or "deotomatization" to create the charm of poetry or to make strange so that it attracts attention.

Keywords: rubayat, structuralism, semiotics

\section{PENDAHULUAN}

Karya sastra tidak lepas dari unsur semiotik, yaitu penanda (signifier) dan petanda (signified). Penanda merupakan unsur yang berfungsi untuk menandai sesuatu. Sedangkan petanda adalah objek yang ditandai oleh penanda. Menurut Pradobo (2001:68) ada bermacam-macam tanda. Adapun jenis tanda yang 
utama adalah ikon, indeks, dan simbol.

Secara historis, semiotik diperkenalkan oleh dua orang tokoh yaitu Ferdinand de Saussure (1857-1913) dan Charles Sander Pierce (1839-1914). Saussure menamakannya dengan semiologi, sedangkan Pierce menyebutnya dengan semiotik. Menurut Preminger (2001:85) perbedaan pendapat dari kedua tokoh ini adalah menurut Pierce, semiotik dikerjakan melalui tipologi tanda-tanda dan metabahasa yang merupakan perluasan logika. Sedangkan Saussare berpendapat bahwa linguistik dapat dijadikan model untuk semiotik karena linguistik menekankan hakikat tanda konvensional.

Dalam pembahasan sastra melalui semiotik, Eco dalam (Kunne-Ibsch, 1998:213) menerapkan teori dari konsepnya mengenai overcoding, yaitu proses sebagai hasil konvergensi berbagai kode dalam sebuah elemen tertentu, makna tambahan diperoleh. Konvergensi dan/atau interferensi stilistika-retoris atau kode-kode ikonologis dengan kode linguistik merupakan kasus yang tepat, dengan demikian teks sastra dan wacana idiologis (yang menyampaikan "hal-hal yang mustahil") ke dalam jajaran obyek untuk dipelajari (diteliti) oleh semiotika.

Dalam perkembangannya teori semiotik tidak bisa lepas "bebas" dari teori strukturalisme. Sesungguhnya, teori semiotik itu merupakan perkembangan dari strukturalisme. Teori strukturalisme-semiotik merupakan teori kritik sastra objektitif. Dikemukan Abrams dalam Pradobo (2003:140), ada empat pendekatan terhadap karya sastra, yaitu (1) pendekatan mimetik yang menganggap karya sastra sebagai tiruan alam (kehidupan); (2) pendekatan pragmatik yang menganggap karya sastra adalah alat untuk mencapai tujuan tertentu; (3) pendekatan ekspresi perasaan, pikiran, dan pengalaman penyair (sastrawan); dan (4) pendekatan objektif yang menganggap karya sastra sebagai sesuatu yang otonom, terlepas dari alam sekitar, pembaca, dan pengarang. Oleh karena itu, dalam kritik ini yang penting adalah karya sastra sendiri, yang khusus dianalisis struktur intrinsiknya.
Pada syair Melayu klasik karya Hamzah Fansuri terdapat kasus semiotik yang kompleks, salah satu contohnya adalah Syair Rubayat. Tidak hanya penanda dan petanda dalam bentuk indeks, tetapi juga terdapat dalam bentuk ikon dan simbol. Bahkan simbol merupakan salah satu hal yang terpenting dan merupakan kekuatan dari karya sastra Hamzah Fansuri.

Dalam Madkour (1995:110) dijelaskan bahwa pada kenyataannya tidak ada penciptaan dalam arti yang dikatakan oleh para teolog Islam, tetapi semata-mata emanasi dan penampakan, karena segala yang ada (al-Maujat) adalah penampakan Ilahi dan ekspresi dari sifat-sifat suci. Sifat apapun yang kita berikan kepada Allah, maka kita adalah (seperti) sifat itu. Nama apapun yang kita berikan kepada sesuatu, maka sesuatu itu adalah yang diberi nama itu.

Sebagaimana yang telah diungkapkan di atas, karya Hamzah sangat dipengaruhi oleh Wihdah Al-Wujud (Pantheisme). Karyanya tersebut sejalan dengan Ibnu 'Arabi yang mengilustrasikan bahwa ketuhanan punya makna abstrak yang non-personal, nyaris tidak tersifati, dan sifat Tuhan Yang Unik (al-Wihdah) adalah al-Wujud.

Sebagai lazimnya penyair sufi, sajak-sajak Hamzah penuh dengan rindu-dendam: rindu kepada Mahbubnya, Kekasihnya, Khaliknya, Allah Yang Maha Esa. Karena kerinduannya yang amat dalam kepada Sang Khalik, membuatnya seakan-akan telah menyatu dengan Tuhannya. Tidak ada lagi jarak antara hamba dengan Sang Pencipta, sehingga ketika ia berbicara ia berkata-kata dengan lidah Khaliknya, ia mendengar dengan telinga Khaliknya, melihat dengan mata Khaliknya, mencium dengan hidung Khaliknya, karena jasadnya telah luluh dalam Khaliknya, Mahbub yang dirindukannya itu (Ara,1995:495).

Untuk model kajian ini, penulis memilih karya-karya Hamzah Fansuri dalam bentuk puisi. Hal ini dipilih karena tampak memiliki unsur-unsur kepuitisan yang "lengkap" untuk keperluan analisis, seperti yang telah dipaparkan di atas. Puisi-puisi Hamzah Fansuri bagus 
sekali dianalisis untuk keperluan pemahaman puisi lebih lanjut. Menganalisis sastra atau mengkritik karya sastra (puisi) adalah usaha menangkap makna dan memberi makna kepada teks karya sastra (puisi). Untuk memahami puisi dengan menggunakan pendekatan strukturalisme-semiotik lebih lanjut, (Pradobo, ibid) mengungkapkan yang terpenting dalam upaya menganalisis untuk pemahaman puisi adalah pembicaraan sajaknya sendiri. Oleh karena itu, sajak harus dianalisis struktur dalamnya (inner structure-nya). Dengan demikian, sajak dapat dimengerti lebih mendalam dan menyeluruh. Untuk dapat memenuhi analisis struktur dalam puisi dipilih teori dan metode strukturalisme-semiotik yang merupakan yang memusatkan perhatiannya pada karya sastra sendiri.

\section{METODE}

Jenis penelitian ini adalah kualitatif dengan pemaparan naratif deskriptif. Sugiyono (2009:15) mengatakan bahwa penelitian kualitatif merupakan metode penelitian yang berlandaskan pada filsafat pospositivisme, digunakan untuk meneliti pada kondisi objek yang alamiah. Oleh karena itu, instrumen penelitian adalah peneliti sendiri dengan intuisi sebagai alat penentu. Sumber data penelitian ini adalah Rubayat Hamzah Fansuri. Data yang diambil berupa keseluruhan struktur Rubayat Hamzah Fansuri dengan makna-makna yang termaktub di dalamnya. Pengumpulan data menggunakan metode simak dan teknik catat. Dalam pengumpulan data tersebut, peneliti menyimak keseluruhan struktur Rubayat Hamzah Fansuri. Kemudian mencatat data-data yang diperlukan untuk bahan analisis. Analisis menggunakan kombinasi metode agih dan metode padan yang merujuk pada model analisis strukturalisme-semiotika. Metode agih yang digunakan adalah teknik bagi unsur langsung (BUL). Teknik bagi unsur langsung berupa membagi satu konstruksi kebahasaan menjadi beberapa bagian sehingga membentuk kontruksi yang dimaksud (Kesuma, 2007:54-55). Metode padan yang digunakan adalah teknik pilah unsur penentu (PUP). Analisis makna meng- gunakan metode padan dengan daya pilah pragmatis yang merujuk pada model analisis semiotika. Sajian hasil analisis data dilakukan dengan metode formal dan informal. Penyajian data secara formal adalah penyajian hasil analisis dengan memakai gambar, tabel, grafik, dan sebagainya. Sementara itu, penyajian hasil analisis secara informal adalah penyajian hasil analisis data memakai kata-kata (Sudaryanto, 1993:145).

\section{HASIL DAN PEMBAHASAN}

\section{Pembacaan Heuristik}

Pembacaan heuristik merupakan pembacaan semiotik tingkat pertama. Pembacaan dalam bentuk ini belum mampu memberikan makna sajak yang sebenarnya karena hanya terbatas pada pemahaman arti bahasa berdasarkan konvensi bahasanya. Untuk mempertajam dan memperjelas makna dari sajak maka pembacaan heuristik harus diulang kembali dengan bacaan retroaktif dan ditafsirkan secara hermeneutik berdasarkan konvensi sastra (puisi), yaitu sistem semiotik tingkat kedua.

\section{RUBAYAT}

Hamzah Fansuri di dalam Mekkah

Mencari Tuhan di Baitil Ka'bah

Dari Barus ke Kudus terlalu payah

Akhirnya dijumpa di dalam rumah

Hamzah miskin orang uryani ${ }^{1}$

Seperti Ismail menjadi qurbani

Bukannya Ajami ${ }^{2}$ lagi Arabi

Senantiasa wasil ${ }^{3}$ dengan yang baqi

Hamzah nin asalnya Fansuri

Mendapat wujud di tanah Shar Nawi ${ }^{4}$

Beroleh khilafat ilmu yang ali ${ }^{5}$

Dari Abdul Kadir Sayyid Jilani ${ }^{6}$

Hamzah Shar Nawi terlalu hapus

Seperti kayu sekalian hangus

Asalnya laut tiada berarus

Menjadi kapur di dalam Barus

Aho segala kamu anak alim 
Jangan bersahabat dengan yang zalim

Karena Rasulullah sempurna hakim

Melarang kita selain khadim

Kunjung-kunjung di Bukit Tinggi

Kolam sebuah di bawahnya

Wajib insan mengenal diri

Sifat Allah pada tubuhnya

Nurani kenyataan yang pasti

Supaya terang laut yang dalam

Berhenti angin ombakpun mati

Menjadi sultak kedua alam

Hamzah Fansuri terlalu karam

Di dalam laut yang maha dalam

Berhenti angin ombak pun padam

Menjelma sultan kedua alam

(Hadi, 1996:219)

\section{Bait ke-1}

Hamzah Fansuri (sedang berada) di dalam (kota) Mekkah. (Ia sedang) mencari Tuhan di (dalam) Baitil Ka'bah. (Jarak tempuh) dari Barus (hingga sampai) ke Kudus (sangat jauh dan sulit, hingga membuat perjalanan yang dilakukannya) terlalu payah. (Namun) akhirnya (ia menjumpai apa yang dicarinya yaitu Tuhan) di dalam rumah (dalam dirinya).

\section{Bait ke-2}

Hamzah (adalah) orang (yang) miskin (tetapi ia mempunyai hati yang bersih) uryani. (Kebersihan hati Hamzah) seperti Ismail (yang bersedia dengan ikhlas) menjadi qurban (oleh bapaknya Ibrahim atas perintah Allah). (Hamzah) bukannya (berasal dari keturunan orang) Ajami (dan juga bukan berasal dari keturunan orang) Arabi. (Namun ia) senantiasa wasil dengan Yang Baqi (dekat dengan Tuhan yang kekal).

\section{Bait ke-3}

Fansuri (adalah nama kampung halaman) Hamzah, (dan ia) (ber) asal (dari sana). (Tetapi ia) mendapat(kan) wujud (ilmu tentang keagamaan) di tanah Shar Nawi (kota di Siam
Lama tempat berkumpulnya pedagang dan cendikiawan muslim). (Di tempat itulah ia) beroleh khilafat ilmu (pengetahuan ilmu) yang ali (ilmu berguna dan ilmu mulia). Dari (seorang sufi Persia, pendiri tarekat Qadariyah yang bernama) Abdul Kadir Sayyid Jilani.

\section{Bait ke-4}

(Ketika) Hamzah (berada di kota) Shar Nawi (ia) terlalu hapus (belajar ilmu agama dengan sungguh-sungguh). (Kesungguhannya mempelajari ilmu agama diibaratkan) seperti kayu (yang terbakar) sekalian hangus. (Ia mengibaratkan ilmu seperti) asalnya laut (yang sedang tenang) tiada berarus. (Ilmu yang bermanfaat akan menyatu dengan orang yang mempelajarinya) menjadi (seperti) kapur (yang menyatu) di dalam Barus.

\section{Bait ke-5}

(Hamzah menyeru dengan seruan) aho segala kamu (orang-orang yang masuk ke dalam golongan) anak (yang) alim (yaitu orangorang yang taat dalam menjalankan perintah agama). Jangan(lah) (kamu mendekat dan) bersahabat dengan (orang-orang) yang zalim. Karena Rasulullah (junjungan manusia adalah manusia yang) sempurna hakim (yang adil). (Rasululullah telah) melarangkan kita sekalian (umatnya untuk berbuat) khadim.

\section{Bait ke-6}

Kunjung-kunjung (berada) di (sebuah) bukit (yang) tinggi. (Terdapat) sebuah kolam di bawahnya. (Setiap) insan (manusia) wajib (hukumnya) mengenal (hakikat) diri(nya) (sendiri). (Karena sesungguhnya) sifat-(sifat) Allah (yang mulia, ada) pada tubuh (manusia itu sendiri).

\section{Bait ke-7}

(Kejujuran hati) nurani (manusia adalah suatu) kenyataan (yang tidak dapat dibohongi dan merupakan sesuatu) yang pasti (pada setiap manusia). (Kejujuran hati nurani akan membuat) laut yang dalam (menjadi) terang (benderang). (Dan akan membuat) 
anginnya berhenti (kemudian) ombakpun (akan) mati. (Nurani akan) menjadi sultan (pemimpin untuk) kedua alam (alam nyata dan alam gaib).

\section{Bait ke-8}

Hamzah Fansuri (menyelam) terlalu (jauh dan) karam. (Ia menyelam) di dalam laut yang maha dalam. Angin(nya) (akan) berhenti (demikian juga) ombak(nya) pun (akan) padam. (Dan ia akan) menjelma (menjadi) sultan (pemimpin) (di) kedua alam (alam nyata dan alam gaib).

\section{Pembacaan Retroaktif atau Hermeneutik}

Dalam pembacaan hermeneutik ini sajak dibaca berdasarkan konvensi-konvensi sastra menurut sistem semiotik tingkat dua. Konvensi sastra yang memberi makna itu di antaranya konvensi sastra yang memberikan makna itu di antaranya konvensi ketaklangsungan ucapan (ekspresi) sajak (puisi). Dikemukan Reffater dalam Pradobo (2001:97) ketaklangsungan ekspresi sajak itu disebabkan oleh (1) penggantian arti (displacing of meaning), (2) pemoncongan atau penyimpangan arti (distorting of meaning); dan (3) penciptaan arti (creating of meaning). Penggantian arti berupa penggunaan metafora dan metonimi; penyimpangan arti disebabkan oleh ambiguitas, kontradiksi, dan nonsense; dan penciptaan arti disebabkan oleh pemanfaatan bentuk visual, misalnya enjambemen, persajakan, homologeus (persejajaran bentuk maupun baris), dan tipografi.

Dalam pembacaan retroaktif ataupun hermeneutik, utamanya dilakukan terhadap bahasa kiasan ataupun secara khusus metafora dan ambiguitasnya. "Rubayat" berarti nyanyian tentang kerinduan, kegelisahan dan pencarian; ingin bertemu dengan Sang Kekasih (Tuhan) untuk menghambakan diri dengan seikhlas-ikhlasnya.

\section{Bait ke-1}

Hamzah Fansuri sedang berada dan berjalan dalam kota suci umat Islam yaitu kota
Mekkah (Mesjidil Haram). Ia melakukan tawaf dan sai'i (mengelilingi Kakbah sambil mengagungkan asma Allah dan lari-lari kecil dari bukit Safa ke Marwah). Hal itu dilakukannya untuk mencari Tuhan (hakikat Tuhan). Mana tahu bisa bertemu dengan Tuhan di Baitil Kakbah. Ia telah melakukan perjalanan suci (Kudus) yang sangat jauh dan melelahkan (secarafisik)darikampunghalamannya(Barus). Akhirnya ia berhasil menjumpai (hakikat Tuhan) di dalam rumah (dalam dirinya sendiri).

\section{Bait ke-2}

Hamzah Fansuri adalah orang miskin (sedikit mengetahui ilmu pengetahuan tentang agama). Tetapi ia mempunyai hati yang bersih dan ikhlas untuk mempelajari ilmu agama (uryani). Ketulusan dan ikhlasan hatinya tersebut seperti keikhlasan dan ketulusan Nabi Ismail yang dijadikan korban (disembelih) oleh bapaknya Nabi Ibrahim (atas perintah Tuhan). Ia bukan berasal dari bangsa Ajami (orang Persia) dan bukan pula dari bangsa Arab (orang Persia dan Arab dipercaya memiliki ilmu pengetahuan agama; terutama agama Islam lebih tinggi dari suku bangsa lainnya di dunia). Walaupun ia bukan berasal dari bangsa Persia dan Arab tetapi ia senantiasa dekat (wasil) dengan Tuhan (Yang Baqi).

\section{Bait ke-3}

Hamzah berasal dari negeri Fansur (sebuah negeri yang damai di nusantara; kemungkinan terletak di Aceh). Namun ia menuntut dan mendalami ilmu agama di Kota Siam Lama (tempat berkumpulnya pedagang dan cendikiawan muslim). Di kota inilah ia memahami ilmu tasawuf dengan mendapatkan hakikat wujud Tuhan dengan makhluk (secara batiniah menurut ilmu suluk). Di samping itu, ia juga memperoleh manfaat (khifalat) ilmu agama yang mulia (ali) untuk dijadikan pedoman hidup di dunia dan akhirat dari para cendikiawan muslim terutama dari Abdul Kadir Sayyid Jilani (seorang sufi Persia. Pendiri tarekat Qadariyah). 


\section{Bait ke-4}

Hamzah adalah orang yang terlalu rindu ingin bertemu dengan kekasihnya (Tuhan). Oleh karena itu, ia mempelajari ilmu agama (Islam) di Kota Shar Nawi dengan bersungguh-sungguh. Ia larut dalam ilmu yang dipelajarinya tersebut (terlalu hapus) karena seriusnya ia mempelajari seluk-beluk ilmu agama (Islam). Baginya tidak ada hari tanpa belajar dengan harapan dapat bertemu dengan kekasihnya itu. Keseriusannya tersebut seperti kayu yang terbakar sekalian hangus menjadi abu. Ilmu itu kalau tidak dipelajari dengan sungguh-sungguh (hanya mempelajari dengan setengah-setengah; tidak sampai pada tahap makrifat maka akan sia-sia belaka karena ilmu itu tidak mengalir dengan sendirinya, harus dicari dan pelajari). Ilmu itu ibarat asalnya laut tiada berarus. Hamzah sangat menyadari hal itu. Oleh karena itu, ia menyatu dengan ilmu (Allah). Tidak dapat dipisahkan lagi. Ibarat kapur yang menyatu dengan Barus.

\section{Bait ke-5}

Hamzah memberitahukan kepada semua orang yang beriman (orang-orang baik; orang-orang yang mengetahui dan menjalankan perintah Tuhan). Aho segala kamu anak alim jangan bersahabat dengan orang yang zalim (orang-orang jahat; orang-orang yang durhaka dan tidak melaksanakan peintah Tuhan; dalam konteks agama Islam). Kebenaran dan perintah Tuhan (firman) telah diturunkan kepada Rasulullah (Nabi Muhammad saw) dalam kitab Al Quran (penyempurnaan kitab-kitab sebelumnya; Taurat, Zabur dan Injil yang diturunkan Tuhan kepada Nabi Daud, Musa, dan Isa). Rasulullah adalah seorang pemimpin untuk seluruh alam yang sempurna dan hakim yang adil (tidak berat sebelah; mengatakan dengan tegas yang benar itu benar dan yang salah itu salah). Rasulullah menyuruh seluruh makhluk untuk beriman kepada Tuhan (menjalankan semua perintah Tuhan dan meninggalkan larangan-Nya).

\section{Bait ke-6}

Kunjung-kunjung terletak di sebuah bukit yang tinggi. Di bawahnya terdapat sebuah kolam yang indah. Setiap insan (manusia) wajib hukumnya untuk mengenal hakikat diri (mempelajari wujud dan zat makhluk menyatu dengan wujud Allah dan zat Allah). Hal ini dimaksudkan untuk mengetahui bahwa manusia itu adalah hamba. Tuhan akan dekat dengan hamba-Nya jika hamba tersebut dekat dengan-Nya. Sifat-sifat Allah yang maha suci terdapat dalam tubuh setiap makhluknya (faham wujudiyah; mempercayai sifat, zat dan wujud Allah menyatu dengan setiap makhluk ciptaan-Nya).

\section{Bait ke-7}

Pada hakikatnya hati nurani manusia akan selalu menyatakan kebenaran. (Hal ini adalah kenyataan yang pasti. Walaupun banyak manusia yang mengkhianatinya; mereka masuk ke dalam golongan orang-orang yang merugi; orang yang akan mendapat azab Allah di dunia dan akhirat). Hal inilah adalah kenyataan dari kuasa Tuhan. Hakikat hati nurani manusia yang selalu menyatakan kebenaran tersebut akan menerangi (membawa kedamian) di dunia dan kebahagiaan yang abadi di akhirat (supaya terang laut yang dalam). Kebenaran dalam hati nurani akan menghentikan setiap kebatilan; orang-orang yang merusak tatanan kehidupan di dunia; orang-orang yang ingkar dengan kekuasaan Tuhan (Berhenti angin ombakpun mati). Mengikuti kebenaran hati nurani dan menjalankan semua perintah Tuhan dan meninggalkan larangan-Nya akan membawa kebahagiaan yang hakiki dunia dan akhirat (menjelma menjadi sultan kedua alam).

\section{Bait ke-8}

Hamzah Fansuri adalah orang yang rindu ingin bertemu dengan kekasihnya (Tuhan). Ia (terlalu karam) larut dan menyatu dengan zat Tuhan dan wujud Tuhan (secara batiniah). Secara hakikat zat dan wujud Tuhan itu sangat dalam. Tidak dapat diselami (diketahui) sepenuhnya oleh manusia. Hal ini sudah merupakan ketentuan Tuhan. Tetapi Tuhan ti- 
dak melarang manusia untuk mempelajarinya (Tuhan Maha Tahu apa yang dikerjakan dan apa yang disembunyikan hamba-Nya). Atas dasar inilah Hamzah Fansuri menyelami ilmu Tuhan (tentunya dengan keterbatasan sebagai manusia). Ilmu Tuhan itu seperti laut yang maha dalam tidak mempunyai dasar. Pada tahap tertentu manusia tidak akan mampu untuk menyelaminya (berhenti angin ombak pun padam). Namun mempelajari dan mendalami ilmu tentang Tuhan tersebut tidak akan sia- sia. Ia akan menjadi pembimbing (sultan) bagi manusia pada kedua alam (dunia dan akhirat; nyata dan gaib).

\section{Tema dan Masalah}

Tema merupakan inti atau esensi karya sastra dan kristalisasi dari seluruh peristiwa dan kejadian yang dipaparkan dalam karya sastra. Berdasarkan pembacaan di atas, tema "Rubayat Hamzah Fansuri" itu dapat dirumuskan menjadi subtema pada tabel berikut.

\section{Tabel 1. Subtema dan Masalah Rubayat Hamzah Fansuri}
Bait Subtema
Masalah
1 rindu bertemu Tuhan menemukan hakikat petualang yang miskin Tuhan dalam dirinya sendiri
2 rindu bertemu Tuhan mempunyai hati ikhlas seperti Nabi Ismail melakukan perjalanan jauh dari Barus menuju Mekkah
3 berasal dari Fansur dan belajar tasawuf di Kota belajar hakikat Tuhan Siam Lama. Ia juga berguru pada Abdul Kadir Sayyid Jilani
4 rindu bertemu Tuhan bersungguh-sungguh belajar ilmu tentang ketuhanan sampai tahap makrifat ketuhanan di Kota Shar Nawi
5 jangan berkumpul dengan orang zalim sebagai manusia biasa sulit menjadi sebagaimana dicontohkan oleh Nabi pribadi selayaknya Nabi Muhammad Muhammad saw saw (pemimpin yang sempurna)
6 wajib mengenal hakikat diri faham wujudiyah
7 pada hakikatnya hati nurani manusia selalu menyatakan kebenaran
perbuatan manusia sering bertentangan dengan hati nurani
8 mencapai tahap makrifat Perjuangan yang tidak mudah untuk sampai pada tahap makrifat

\section{Pembacaan Unsur-Unsur Sajak}

Untuk lebih menjelaskan proses pemaknaan berdasarkan pembacaan hermeneutik itu, sajak perlu dianalisis lebih lanjut secara merenik. Judul "Rubayat Hamzah Fansuri" merupakan sebuah hikayat yang menyirat perjalanan spiritual penyair dalam mencari Tuhan.

\section{Bait ke-1}

"Mekkah" adalah nama sebuah kota yang disucikan oleh umat Islam. Di Mekkah terdapat suatu bangunan yang bernama Baitil Ka'bah yang merupakan kiblat umat Islam. Penyair menempuh perjalanan jauh untuk mencari Tuhan. Ia akhirnya menemukan Tuhan "akhirnya dijumpa di dalam rumah". Rumah adalah metafora yang mengiaskan Baitil Ka'bah sebagai arah atau tempat untuk bersujud.

\section{Bait ke-2}

"Hamzah miskin" adalah metafora bahwa ia sedikit menguasai ilmu agama. Namun se- 
cara denotasi Hamzah Fansuri memang tidak mempunyai harta benda keduniawian yang banyak. Sedangkan "orang uryani" adalah kiasan yang melambangkan kebersihan dan keikhlasan hati Hamzah Fansuri dalam perjuangannya mencari Tuhan.

"Seperti Ismail yang menjadi qurban" adalah perbandingan makna dari baris ke-1 dan baris ke-2 yang merupakan homologues (persejajaran) yang saling beranalog. "Hamzah miskin" sejajar dengan "seperti Ismail", kiasan orang tidak mementingkan segala harta dunia. Sedangkan "orang uryani" sejajar dengan "menjadi qurban", yaitu keikhlasan hati mereka dalam menjalankan apa diperintahkan Tuhan.

"Bukannya Ajami lagi Arabi" pada baris ini terjadi lagi persejajaran (homologues) dengan bait ke-1 baris ke-3 yaitu menerangkan secara denotatif asal-usul sang penyair. Pada bait ke-1 baris ke-3 tersebut diterangkan bahwa Hamzah Fansuri berasal dari daerah yang bernama Barus-kemungkinan daerah ini terletak di perbatasan antara wilayah Sumatra Utara dan Aceh sekarang. Ia bukan orang 'Ajami' Persia atau Arab. "Senantiasa wasil dengan Yang Baqi" baris ini merupakan penjelasan lebih lanjut dari baris ke-1 "orang uryani" yaitu mengungkapkan secara konkret mengenai jiwa sang penyair yang sangat dekat dengan Tuhan. Secara logika orang yang dekat dengan Tuhan pasti mempunyai hati yang bersih dan ikhlas.

\section{Bait ke-3}

"Hamzah nin asalnya Fansuri" pada baris ini terjadi kembali persejajaran dengan bait ke- 1 baris ke- 3 dan bait ke- 2 baris ke-3 yaitu tentang asal-usul pengarang. Namun pada baris ini nama asalnya bernama "Fansuri" sedangkan pada baris ke-3 bernama "Barus". Hal ini membuat suatu pertanyaan apakah Barus dan Fansuri merupakan wilayah yang sama dengan nama yang berbeda? "Mendapat wujud" adalah kiasan orang yang sudah mengetahui dan mempunyai ilmu pengetahuan, artinya orang yang sudah mempunyai pendirian dan mengetahui hakikat dirinya. Dalam baris ini diterangkan bahwa Hamzah Fansuri mempelajari ilmu pengetahuan tersebut-terutama ilmu mengenai seluk-beluk agama Islam-“di tanah Shar Nawi" - sebuah kota di Siam Lama tempat berkumpulnya pedagang dan cendikiawan muslim. "Beroleh khilafat ilmu yang ali" dalam mempelajari ilmu pengetahuan tersebut penyair memperoleh manfaat sesuai dengan yang diharapkannya yaitu berupa ilmu-ilmu yang "ali" (mulia). Selain mendapatkan ilmu pengetahuan dari para pedagang dan cendikiawan muslim, Hamzah Fansuri juga berguru kepada orang yang pandai terutama "dari Abdul Kadir Sayyid Jilani" - seorang sufi asal Persia, pendiri terekat Qadariyah.

\section{Bait ke-4}

"Hamzah Shar Nawi", pada baris ini penyair tidak lagi menerangkan asalnya dari Fansuri tetapi Hamzah sudah mengganti nama belakangnya dengan daerah tempat ia menuntut ilmu pengetahuan. Hal ini mungkin disebabkan karena Hamzah sangat bersungguh-sungguh menuntut ilmu di Shar Nawi "terlalu hapus". "Seperti kayu" adalah kiasan yang bersifat perbandingan dengan baris ke-1 dan merupakan pelurusan makna "sekalian hangus". Baris ini adalah metafora yang mengiaskan kesungguhan Hamzah dalam menuntut ilmu pengetahuan. Ia tidak mau setengah-setengah dalam menuntut ilmu pengetahuan tersebut. Ibarat kayu yang sedang terbakar biar sekalian hangus. "Asalnya laut tiada berarus", baris ini merupakan kelanjutan keterangan dari baris ke-2. Selain itu, baris ini juga merupakan metafora yang mengiaskan ilmu pengetahuan tersebut tidak akan mengalir (datang) dengan sendirinya kepada seseorang. Ia harus dicari dan dipelajari. "Menjadi kapur di dalam Barus", baris ini merupakan persejajaran dengan baris ke-2 yang mempunyai makna yang sama yaitu mengenai kesungguhan penyair dalam menuntut ilmu pengetahuan.

\section{Bait ke-5}

"Aho sekalian kamu anak alim", baris ini, merupakan kalimat konkret yang merupakan ajakan penyair kepada pembaca (orang yang alim). Baris kedua merupakan kelanju- 
tan keterangan makna dari baris ke-1. Penyair mengajak pembaca untuk "jangan bersahabat dengan yang zalim" karena orang zalim adalah sangat identik dengan orang jahat. Baris ke-1 dan baris ke-2 tersebut terjadi sinkronisasi sehingga kesinambungan makna tidak terputus dan saling menunjang pemaknaan satu sama lain seperti beranalog.

"Karena Rasulullah sempurna hakim", pada baris ini seolah-olah terjadi pemutusan hubungan (makna) dengan baris ke-1 dan baris ke-2. Sebenarnya tidak terputus sama sekali tapi terjadi hubungan timbal-balik (sebab-akibat) yang sangat "halus". Hal tersebut dapat kita lihat pada orang yang zalim tidak mungkin menjadi seorang hakim yang sempurna (berlaku adil) seperti Rasulullah (Nabi Muhammad saw). Baris ini juga merupakan kalimat konkret dan tidak mengandung metafora (kalimat kiasan). "Melarang kita sekalian khadim", baris ini merupakan kalimat penghubung makna pada bait ke-5 ini secara keseluruhan. Terutama pada baris ke-2, baris ke-3 dan baris ke-4. Pada baris ke-2 penyair melarang kita untuk bersahabat dengan orang zalim karena sifat zalim tersebut bukanlah melambangkan sifat Rasulullah yang "sempurna hakim". Dalam ajaran agama Islam sifat Rasulullah harus dicontoh dan dijadikan teladan oleh seluruh umat Islam.

\section{Bait ke-6}

Bait ke-6 ini merupakan pola a-b-a-b yang merupakan pola pantun Melayu secara umum sehingga baris ke-1 dan baris ke-2 merupakan sampiran-hal ini akan dibahas lebih lanjut pada sub judul berikutnya (gaya bunyi sajak). Secara keselurahan bait ke-6 ini berdiri sendiri terlepas dari bait-bait yang ada pada "Rubayat Hamzah Fansuri" yang sedang kita bahas ini. Baik tema maupun isi tidak mempunyai hubungan secara konkret. Seperti telah diungkapkan di atas, baris ke-1 dan baris ke-2 merupakan sampiran sehingga tidak perlu dibahas karena tidak mempunyai pengertian secara khusus yang dapat menunjang pemaknaan dari bait ini. "Wajib insan mengenal diri", baris ke-3 ini merupakan isi dari bait ke-6 yang secara konkret mempunyai pengertian bahwa setiap manusia wajib mengenal hakikat dirinya sendiri. Dengan mengenal hakikat diri sendiri sebagai ciptaan Allah Swt maka akan menimbulkan kesadaran bahwa sesungguhnya setiap individu manusia mempunyai keterbatasan dan hi-dup di dunia tidak kekal. Namun pengertian secara Wujudiyah dengan mengenal hakikat diri maka akan mengenal hakikat Tuhan karena antara manusia-secara umum seluruh ciptaan Tuhan tidak terpisah dengan zat dan wujud Tuhan. "Sifat Allah pada tubuhnya", baris ke-4 ini merupakan keterangan yang menguatkan pengertian baris ke-3. Seperti telah diungkapkan di atas bahwa sifat serta zat dan wujud Allah Swt menyatu "lebur" dalam tubuh manusia.

\section{Bait ke-7}

Secara umum bait ke-7 juga saling bersinkronisasi dengan bait-bait yang ada dalam "Rubayat Hamzah Fansuri" ini. "Nurani kenyataan yang pasti", baris ke-1 ini tidak mengandung metafora ataupun pengertian konotasi, tetapi mempunyai pengertian secara konkret atau denotasi. "Nurani", secara batiniah merupakan "kata hati" (ruh) yang selalu menyatakan kebenaran yang hakiki. Jadi nurani yang ada pada setiap individu manusia adalah "kenyataan yang pasti" dan akan selalu senyata kebenaran. Walaupun secara konkret manusia mengungkapkan suatu kebohongan tapi sebenarnya nuraninya akan membantah kebohongan yang telah diungkapkannya tersebut. "Supaya terang laut yang dalam", adalah metafora yang mengiaskan kebenaran yang hakiki. Baris ke-2 ini merupakan keterangan dari baris ke-1. Nurani secara hakiki selalu mengungkapkan kebenaran tersebut, akan menerangi hati setiap manusia. Walaupun manusia tersebut hidup dalam "kegelapan" karena pada hakikatnya kebenaran akan selalu mengalahkan kejahatan. "Berhenti angin ombakpun mati", baris ini juga merupakan metafora yang mengiaskan bahwa nurani akan mengalahkan kejahatan. Pada bait ke-7 ini terlihat dengan jelas sinkronisasi antar baris yang saling mendukung 
pengertian. Baris ke-3 ini menambah kuat pengertian dari baris-baris sebelumnya dalam bait ini. Bagaimanapun jahat dan ganasnya seseorang kalau ia menuruti nuraninya, maka kejahatan dan keganasan tersebut akan hilang dan ia akan menyadari kesalahan-kesalahan yang telah dilakukannya tersebut. "Akan sultan", adalah kiasan yang melambangkan pemimpin untuk dijadikan pedoman pada "kedua alam". "Kedua alam", mempunyai pengertian bahwa kehidupan manusia-setiap makhluk ciptaan Tuhan secara umum, akan menjalani kehidupan pada alam nyata (kehidupan di alam dunia sekarang ini) dan alam gaib (alam kubur dan alam akhirat). Secara keseluruhan dapat kita tarik kesimpulan pada bait ke-7 ini adalah nurani yang selalu menyatakan kebenaran secara hakiki tersebut akan menjadi pemimpin atau pedoman manusia dari kehidupan dunia sampai pada kehidupan alam akhirat.

\section{Bait ke-8}

Secara umum bait ke-8 ini mempunyai pengertian yang sama dengan bait ke- 4 , terutama baris ke- 1 dan baris ke- 2 pada bait ke- 4 dengan baris ke-1 pada bait ke-8. "Hamzah Fansuri terlalu karam", baris ini adalah metafora yang mengiaskan kesungguhan Hamzah dalam menuntut ilmu pengetahuan. Ia tidak mau setengah-setengah dalam menuntut ilmu pengetahuan tersebut. Ia larut dan karam dengan ilmu pengetahuan tersebut. "Di dalam laut yang maha dalam", baris ke-2 ini adalah keterangan lanjutan dari baris ke-1. "Hamzah Fansuri yang terlalu karam" dalam ilmu pengetahuan tersebut, menyelaminya dengan sangat dalam. Dalam hal ini, baris ke- 2 mempunyai dua pengertian yaitu pengertian secara fisik dan batiniah. Secara fisik mempunyai pengertian sebagai berikut; Hamzah Fansuri sangat giat dalam menuntut ilmu pengetahuan, sehingga tidak mempunyai waktu untuk pekerjaan yang lain, sedangkan secara batiniah mempunyai pengertian bahwa Hamzah Fansuri telah mencapai tingkat yang tinggi dalam mempelajari ilmu makrifat Allah Swt. "Berhenti angin ombak pun padam", baris ke-3 ini merupakan metafora yang mengiaskan sang penyair telah melupakan (meninggalkan) semua yang bersifat keduniaan dan kebendaan. Pada tingkat ini Hamzah Fansuri telah memasuki wilayah kesufian. Dalam hal ini, dapat ditarik kesimpulan bahwa awal kepengarangan Hamzah Fansuri dalam aliran sufistik bermula di Shar Nawi ini-hal ini perlu penelitian yang lebih dalam terutama mengenai biografi pengarang. "Menjelma Sultan kedua alam" baris ke-4 ini merupakan pengulangan dari bait ke-7 baris ke-4. Hal ini dimaksudkan untuk menguatkan pentingnya makna dari baris tersebut. Selain itu, penyair seakan-akan ingin menyatakan bahwa tema sentral dari bait ke-7 dan bait ke-8 juga terletak pada baris tersebut. Sehingga terjadinya pengulangan kalimat yang sama pada bait tersebut.

\section{Analisis Gaya Bahasa}

Pengulangan bunyi dalam puisi untuk membentuk musikalitas atau orkestrasi. De-ngan pengulangan bunyi itu, puisi menjadi merdu jika dibaca. Untuk mengulang bunyi ini, penyair juga mempertimbangkan lambang bunyi. Dengan cara ini, pemilihan bunyibunyi mendukung perasaan dan suasana puisi (Waluyo, 1985:90).

\section{(1) Onomatope}

Onomatope adalah tiruan terhadap bunyi-bunyi yang ada. Bunyi-bunyi tersebut diharapkan dapat menimbulkan gema atau pun memberi kesan pada suasana tertentu seperti yang diharapkan penyair. Dalam judul Rubayat bunyi /a/ cukup dominan dipergunakan yang membuat irama dan timbulnya angan serta suasana mendamaikan hati. Namun, perpaduan dengan konsonan /b/ dan /t/ membuat suasana damai tersebut menjadi sesuatu yang penuh dengan gerakan yang terus mencari. Untuk jelasnya onomatope dalam rubayat dapat dilihat tabel berikut. 
Tabel 2. Onomatope Rubayat

\section{Bait dan Bunyi Dominan}

Baris

$\begin{array}{ll}1 / 1 & \text { /a/ } \\ 1 / 2 & \text { /a/ /i } \\ 1 / 3 & / \mathrm{a} / \mathrm{u} / \mathrm{d} / \mathrm{t} / \\ 1 / 4 & / \mathrm{y} / \\ & / \mathrm{m} / \mathrm{l} /\end{array}$

$2 / 1$

/a/ /i/ /n/

$2 / 2,2 / 3,2 / 4 \quad / a / / i / / n /$ dipengaruhi /ng/

$3 / 1$

/a/ / / / n/ kombinasi dengan

$3 / 2$

/s/

/a/ disisipi /u/

$3 / 3$

/d/ / t /

/a/ /e/ /i/ dan /l/ keindahan dan kedamaian

Damai

bergerak dengan kesibukan

pesimistis

gerakan pelan,

menggairahkan, damai, dan mewah

pasrah (mengiba)

penuh pengharapan

lembut, lancar, dan

menyejukkan.

kebencian

keindahan

$3 / 4$

/a/ /i/ /d/ /l/

$4 / 1,4 / 2$,

$4 / 3,4 / 4$

/a/ /u/ /s/

mengejek, lembut, lancar,

dan kadang-kadang

menimbulkan perasaan

menyejukkan.

$5 / 1,5 / 2$,

/a/ dipengaruhi

ketegasan

$5 / 3,5 / 4$

/m/ /n/

$6 / 1$

$6 / 2$

/u/ /i/ /n/ /ng/

$/ \mathrm{t} /$

$6 / 3$

$6 / 4$

/a/ /u/ /b/

sama dengan $6 / 1$ tegas dan cepat

/a/ / / / t/ /h/

keseluruhan /a/ /i//m/ /n/ bait 7 /l/ mengalir pelan, damai, menggairahkan, dan bersifat mewah

\section{Keterangan}

bersifat konstan

kombinasi /a/ dan /i/

memberikan efek dengungan

(echo)

dengungan (echo)

memberikan sugesti

kecepatan

bersifat konstan

bersifat konstan dan elatis gerakan pendek dan cepat mengalir pelan dan bersifat mewah

tegas dan pasti

irama yang terus-menerus dan stabil

echo irama teratur

bersifat sinis

efek dengungan

konsonan eksplosif

dipengaruhi / h/ membuat gerakan menjadi lebih teratur dan bersifat dinamis irama teratur dengan unsur echo

8 sama

dengan 5 


\section{SIMPULAN}

Dalam kajian sajak diperlukan teori dan metode yang dapat memperjelas unsur-unsur sajak yang merupakan satuan-satuan makna. Teori dan metode kajian puisi itu harus dapat dipergunakan untuk menganalisis kompleksitas sajak sebab dalam kajian puisi yang terpenting adalah karya sastra (puisi) itu sendiri. Dengan demikian sajak harus dianalisis unsur dalamnya. Teori dan metode yang sesuai dengan hal tersebut adalah teori strukturalisme-semiotik.

Pembacaan semiotik yaitu pembacaan heuristik dan hermeneutik. Pembacaan heuristik itu memperjelas hubungan antar unsur kebahasaannya dan arti linguistiknya. Pembacaan heuristik belum memberi makna sajak, maka harus dilanjutkan dengan pembacaan hermeneutik untuk memberikan makna sajak. Hal itu disebabkan bahwa sajak itu sebagai sistem tanda tingkat kedua mempunyai konvensi sendiri yang lain dari konvensi bahasa sebagai sistem tanda tingkat pertama.

Dalam pemahaman sastra, khususnya sajak, teori strukturalisme dan semiotik itu tidak dapat dipisahkan. Hubungan antara struktur tanda dan makna itu tidak terpisahkan. Analisis struktural untuk melihat hubungan antar unsurnya, sedangkan penerangan semiotik untuk memberikan arti unsur-unsurnya sebagai tanda yang bermakna.

Secara keseluruhan Rubayat banyak menggunakan metafora. Semua itu merupakan "defamiliarisasi" atau "deotomatisasi" untuk menimbulkan daya pesona sajak atau untuk membuat aneh (making streange) sehingga menarik perhatian. Sebenarnya hal ini, tidaklah terlalu aneh terjadi dalam persajakan di Nusantara dan sastra Melayu secara khususnya.

\section{DAFTAR PUSTAKA}

Ara, L.K. dkk. (1995). Seulawah Antologi Sastra Aceh Sekilas Pintas. Jakarta: Yayasan Nusantara.

Braginsky,V.I.(1993).TasawufdanSastraMelayu
Kajian dan Teks-Teks. Jakarta: R U L. Hadi WM Abdul. (1996). Sastra Sufi Sebuah Antologi. Jakarta: Pustaka Firdaus.

Kesuma, Tri Mastoyo Jati. (2007). Pengantar Metode Penelitian Bahasa. Yogyakarta: Caravastibooks.

Kunne, D.W. Fokkema Elrud-Ibsch.(1998). Teori Sastra Abad Kedua Puluh. Jakarta: PT. Gramedia Pustaka Utama.

Madkaur, Ibrahim. (1995). Aliran dan Teori Filsafat Islam. Jakarta: Budi Aksara.

Pradobo, Rahmat Djoko. (2001). Penelitian Sastra Dengan Pendekatan Semiotik dalam Metodologi Penelitan Sastra. Yogyakarta: PT. Hanindita Graha Widya. (2001). Dewa Telah Mati: Kajian Strukturalisme-Semiotik, dalam Metodologi Penelitian Sastra. Yogyakarta: PT. Hanindita Graha Widya.

(2003).

Beberapa

Teori

Sastra, Metode Kritik, dan Penerapannya. Yogyakarta: Pustaka Pelajar.

Preminger, Alek, dkk, diterjemahkan Pradobo. (2001). Semiotik (Semiologi), dalam Metodologi Penelitian Sastra. Yogyakarta: PT. Hanindita Graha Widya.

Semi, M Atar. (1990). Meode Penilitian Sastra. Bandung: Penerbit Angkasa.

Siegers, Rien T, dialih bahasa Suminto A. Sayuti. (2000). Evaluasi Teks Sastra. Yogyakarta: Adicita Karya Nusa.

Sudaryanto. (1993). Metode dan Aneka Teknik Analisis Bahasa. Yogyakarta: Duta Wacana University Press.

Sugiyono.(2009). MetodePenelitian Kuantitatif, Kualitatif, dan R\&D. Bandung: Alfabeta.

Waluyo, Herman J. (1987). Teori dan Apresiasi Puisi. Jakarta: Penerbit Erlangga. 